\title{
Listening to the Voice of the Patients: The Marketing Function, Market Orientation and Performance in Hospitals in Emerging Markets
}

\author{
E. Asuman Atilla ${ }^{1}$, Dilaver Tengilimoglu², Türkan Dursun-Kilic ${ }^{3}$ and Aykut Ekiyor ${ }^{4}$ \\ ${ }^{1}$ Healthcare Management Department, Gazi University, Ankara, Turkey \\ ${ }^{2}$ Business Administration Department, Atilim University, Ankara, Turkey \\ ${ }^{3}$ Management, Marketing and General Business Department, West Texas A\&M University, \\ Canyon, TX, USA \\ ${ }^{4}$ Healthcare Management Department, Gazi University, Ankara, Turkey \\ E-mail: ${ }^{1}<$ asumanatilla@gmail.com>, ${ }^{2}<$ dilaver.tengilimoglu@gmail.com>, \\ ${ }^{3}<$ tkilic@mail.wtamu.edu>, ${ }^{4}<$ aykutekiyor1974@yahoo.com>
}

KEYWORDS Health Care. Private Organizations. Competition. Customer Focus. Growth. Bed Occupation Ratio

ABSTRACT The present study aims to explore to what extent hospitals adopt a market orientation as their corporate marketing strategy in an emerging-market context which poses many macro-level challenges for health care organizations due to its strong need for economic development, societal development, better quality-of- life (QOL), welfare, ethical practices among others. Hospitals that serve in these markets can benefit from a market orientation since a market-oriented strategy enables them to study understand and respond to their health care customers more effectively. Administrators from 400 private hospitals in Turkey were surveyed. A positive connection was found between the level of the hospital's market orientation and the presence of a formal marketing department that serves as the informational bridge between the hospital and the society. The results of this study revealed that market orientation is positively related to general performance of the hospital. The present study also showed that a statistically significant difference exists between the general performance of the hospitals having a formal marketing department and of those not having one. Market-oriented private hospitals perform better compared to their less market-oriented counterparts. A formal marketing department that connects the hospital to its customers and the society at large plays a pivotal role in the development of market-oriented strategies and operations and improves hospital performance. Managerial and public policy implications of the research results were also discussed.

\section{INTRODUCTION}

Marketing remains a broad and dynamic field. Developments in the social sciences influence how we think about markets, customers, and competition; technological innovations change how organizations reach customers and organizational changes influence how marketing is practiced within firms (Shankar and Carpenter 2012). Marketing has evolved over the past 30 years in health care. Originally, it was viewed with great derision as little more than advertising. The narrow perspective of marketing as only advertising minimizes its contrubution. Market-

Address for correspondence:

Aykut Ekiyor

Faculty of Economics and Administrative Sciences, Healthcare Management Department,

Gazi University, Ankara, Turkey

E-mail: aykutekiyor1974@yahoo.com,

Telephone: +905333527445 ing really brings with it an external perspective that adds a key value in organizational planning (Berkowitz 2010).

Sidney Levy, who has been acknowledged by today's marketers as one of the main contributors to marketing and consumer behavior thoughts in the twentieth century, "questioned the idea that marketing is primarily a narrowly defined business activity and that marketing functions are separate and independent from society" (Harris 2007). It has been observed that "managers in many types of organizations face the same strategic concerns about consumers, product positioning, competition, and the marketing environment” (Harris 2007). With the broadening of the marketing concept, marketing has been applicable to a variety of contexts such as nonprofit, art, entertainment, health care, charitable organizations, professions and political campaigns (Harris 2007). Marketing provides concepts and methods that help many types of businesses to be competitive and successful. 
In spite of its apparent benefits, the adoption of marketing by health care institutions has been quite slow. The applicability of marketing concepts and methods in the health care context has still being questioned from an ethical perspective. Most of not-for-profit organizations such as hospitals exist to benefit the society or citizens and making profit is not among their primary objectives. However, hospitals just like other businesses work in a competitive and dynamic environment. For successful adaptation to change environmental conditions, hospital organizational cultures must incorporate the marketing concept to enhance flexibility and orientation toward the external environment (Arnold et al. 1987). In order to survive in a competitive health care market, hospitals need to utilize marketing methods and concepts to better serve citizens and the larger society.

Marketing has a profound impact on the society through marketing systems. "Marketing alters society and the habitat in which it resides on an extensive and extending scale" (Varey 2013). The marketing concept has been blamed for causing over-production and over-consumption of goods and services that are damaging (Varey 2013), individuals and the society as a whole, environmental polution, and irresponsible use of scarce resources. Marketing has been criticized for being overly profit-driven and not considering primarily the benefits of the society. In spite of this negative perception of it, marketing offers knowledge and methods that can help health care organizations accomplish their altruistic, and societal goals. Marketing can serve the society's interests in the health care sector by enhancing the Quality-Of-Life (QOL), a major dimension of the societal development. Kilbourne (2008) defines marketing, in its broadest sense, as "a provisioning technology, the function of which is to deliver quality of life to the collectivity so engaged”. The development level of nations is assessed by their success in enhancing and maintaining the well-being or quality-of-life of their citizens (Rahtz and Szykman 2008). Marketing has the potential to contribute to the QOL (for example, cost/standard of living, health care, economy, infrastructure, political freedom, social equality, culture and recreation, interpersonal relations, and environment) of the society through improving the health of people (Peterson 2006; Kilbourne 2008). Health care is a major component/determinant of QOL
(Chance and Deshpande 2009; Keller et al. 2009) and is getting increasingly costly (Keller et al. 2009; Samli 2010). The health care dimension of the QOL of a society is related to life expectancy, calorie consumption, availability of physicians and nurses, hospital beds per 1,000 people, clean water access, infant mortality, and public health expenditures/country's Gross Domestic Product (GDP) (Peterson 2006). Marketoriented health care systems can alter many of these variables in positive ways by incorporating the opinion of the health care customers into their strategic planning.

Since marketing and marketing systems affect the economic and societal growth of a country, in emerging markets, businesses can be expected to be more inclined to adopt and utilize marketing concepts and methods. Especially businesses that operate in competitive and dynamic markets can view marketing as an effective tool to establish a competitive position in the consumer market. In such markets, businesses would be in a better market position if they adopt a corporate marketing strategy that is based on a market orientation. The results from the firm-level research suggest that market orientation improves firm performance (Narver and Slater 1990; Jaworski and Kohli 1993). Market orientation is a management philosophy that has been the foundation of corporate marketing management for decades (Narver and Slater 1990; Jaworski and Kohli 1993; Mitchell et al. 2010). There have been two widely-acknowledged perspectives on market orientation (Jaworski and Kohli 1996). These are (1) a behavioral/ activities/ process perspective (Kohli and Jaworski 1990; Day 1994), and (2) a cultural perspective (Narver and Slater 1990; Deshpande et al. 1993; Hurley and Hult 1998). According to Kohli and Jaworski (1990) who see market orientation as a process-based phenomena in organizations, market orientation focuses on "ongoing behaviors and activities in an organization”. Jaworski and Kohli (1996) also include customer and competitor intelligence generation, dissemination of this intelligence throughout the firm, and responsiveness to it.

Market-oriented strategy development allow firms to incorporate the voice of the citizens into the product/service development process. The health care context in almost every society has some elements of subsistence marketplaces where the betterment of basic life circumstances 
is needed, human and economic considerations blur, and the social environment is complex (Viswanathan et al. 2009). The health care markets in many societies' house communities who are economically and/or socially disadvantaged (for example, agricultural communities, unemployed populations, urban poor, illiterate people, ethnic/racial subcultures, etc.) are not fully developed. Market orientation, as a corporate marketing strategy, allows health care organizations to serve their regular markets as well as subsistence marketplaces (individuals, communities, entrepreneurs, etc.) not as commercial markets to sell their offerings to, but as communities to understand and learn from The University of Illinois at Urbana-Champaign-College of Business Website (The University of Illinois at Urbana-Champaign 2014). Health care organizations can examine, learn from and respond to their subsistence market places using market research. According to Viswanathan et al. (2009), purposive understanding of subsistence marketplaces lead to better addressing of customer needs and welfare as could be demonstrated by the following outcomes: Designing products that improve life circumstances, and developing multifaceted, product related means to enhance welfare, co-creating offerings with subsistence, buyers and sellers, and engendering trust in customer interactions and business practices. In emerging markets where there is a greater need for economic and societal development and the betterment of the QOL, the health care markets contain elements which are more in line with the characteristics of subsistence marketplaces. In both developed and developing societies, deeply-rooted economic, societal and health problems can be better understood and tackled with the help of market-oriented heath care establishments. The term, health marketing, here signifies the systematized application of the marketing principles within the very broad, heterogeneous, and complex field of health. Although many authors have praised the emergence of health marketing as a distinct field of research provided clear and integrative definitions. Indeed, health marketing refers to a number of realities, for example, marketing of the life sciences, social marketing, and marketing of health services, but few ultimately have these (Crie and Chebat 2013).

Furthermore, from the economic perspective, according to Loubeau and Jantzen (1998), the dynamic nature of the health care industry forces health care executives to develop effective strategic plans in order to increase revenues, decrease costs and develop possible alliances with other health care providers. Health care executives increasingly demand current and reliable market intelligence to make better strategic decisions. They need a wide spectrum of market information originating from the society to make sound decisions. It is important for hospitals to understand consumer perceptions and the position of the institution in the marketplace, and develop and test new ideas, services and solutions (Loubeau and Jantzen 1998). Hospitals, like any other businesses, have customers that include patient, physician, or managed care organization that has a choice among providers (Loubeau and Jantzen 1998). Good market intelligence helps health care organizations understand the needs, wants, preferences, attitudes and purchase decision-making processes of their customers. Hospitals need to know how health care customers define and perceive quality, service, convenience and value, and what roles these features play in their purchase decision. At a broader level, hospitals need to address issues such as competitive position and vulnerability, expanding markets for existing products through alternative delivery systems, and hospital image, reputation and identity as perceived by the society (Loubeau and Jantzen 1998). Market intelligence is a key to the success of any businesses. On the basis of market intelligence gathered, hospitals can develop better solutions to customer problems. And not only individuals but also, collectively, the whole society can benefit from the market information gathered and used by hospitals. Chance and Deshpande (2009) argued that "in a bottom-up spillover model... in which satisfaction in different life domains aggregates to overall life satisfaction, increasing access to health care and medicines is an important step toward improving consumer well-being”. Market orientation enables health care organizations to satisfy their customers by instilling the customer's voice in their offerings, processes, policies, and practices regardless of how they define their business contexts.

Health care markets in this context display the typical characteristics of subsistence marketplaces with strong needs for economic and social development, improvement of the QOL, welfare, ethical business practices and so on. 
Hospitals that serve in these markets can benefit from a market orientation since market orientation allows them to study, understand and respond to their health customers more effectively. Also, health care markets in developing countries may be very competitive and dynamic and in constant transformation. In order to survive and compete in a dynamic market, hospitals may prefer to pursue market-oriented management strategies and policies.

There are two widely accepted perspectives on market orientation (Jaworski and Kohli 1996) in the literature: A behavioral/ activities/ process perspective (Kohli and Jaworski 1990; Day 1994), and a cultural perspective (Narver and Slater 1990; Deshpande et al. 1993; Hurley and Hult 1998). According to the behavioral perspective suggested by Kohli and Jaworski (1990), market orientation focuses on "ongoing behaviors and activities in an organization” Jaworski and Kohli (1996) which include customer and competitor intelligence generation, dissemination of this intelligence throughout the firm, and responsiveness to it. According to the cultural perspective suggested by Narver and Slater (1990), market orientation is "the organizational culture that most effectively and efficiently creates the necessary behaviors for the creation of superior value for buyers and, thus, superior performance for the business”. According to Narver and Slater (1990), market orientation has three important components which are customer orientation, competitor orientation, and interfunctional coordination (Slater and Narver 1990). This paper adopts a behavioral perspective on market orientation.

Research on market orientation has emerged during the last two decades and received broad interest from marketing scholars. A growing body of research on market orientation have adopted a firm-level approach to market orientation and explored the relationship between market orientation and business performance in a single or a multi-industry context in the United States of America (U.S.A.) as well as in international settings (Deshpande et al. 1993; Slater and Narver 1994a; Greenley 1995; Pelham and Wilson 1995; Han et al. 1998). Much of the work on market orientation has been conducted in manufacturing settings (Kumar and Subramanian 2000). Few studies have explored market orientation as sustainable market orientation from a macro perspective (Viswanathan et al. 2009; Mitchell et al. 2010).

The effect of market orientation on performance in the health care industry has been investigated by few studies (Naidu and Narayana 1991; Raju et al. 1995; Kumar et al. 1998; Wood et al. 2000; Wrenn 2002) mostly in the Western health context. These studies have generally found a positive relationship between market orientation and performance (Kumar et al. 1998; Kumar and Subramanian 2000; Raju et al. 2000; Wood et al. 2000; Wrenn 2002). However, it should be acknowledged that hospitals have still been quite slow and hesitant in accepting and adopting marketing concepts and methods. Most of the time, hospitals mistakenly view market orientation as public relations and advertising (Arnold et al. 1987). Although public relations and advertising are quite vital functions for hospitals, the studies that have been conducted suggest that the true scope of a market orientation goes beyond these functions and includes many other dimensions. Therefore, a better understanding of the scope and impact of a market orientation on hospitals, individuals and the society at large is quite important in today's dynamic and competitive health care landscape and this paper aims to serve this purpose.

\section{METHODOLOGY}

\section{Objectives of the Study}

The present study aims to explore to what degree health care organizations, namely hospitals, adopt a market orientation as their corporate marketing strategy in an emerging-market context.

More specifically, the purposes of the study are three-fold: (1) to what extent private hospitals in a developing-country context are marketoriented, (2) how having a formal marketing department as an informational bridge between the hospital and the society influences market orientation and performance of the hospital, and (3) whether the level of market orientation is associated with the general and technical performances of the hospital.

The Turkish health care market was chosen as a research context for the study, since it is a competitive market in transformation and has subsistence marketplaces posing many challeng- 
es for health care organizations. In Turkey, many private hospitals work in a complex and turbulent environment. The major environmental dynamic forces that affect private hospitals include increased competition, technological and social changes and trends, and governmental regulations. The health care industry in Turkey has been in the process of a rapid transformation from being the heavily government-controlled health care industry to being the less government-controlled one for the last two decades. The increasing number of private health institutions combined with a large number of government health institutions has created competitive challenges for private hospitals. Turkey is an emerging market that has strived to achieve sustainable economic growth and societal development for its citizens for decades.

The study aims to contribute to the literature in four ways: First, the subject matter of this research study, market orientation- is a field which brings together the micro and macro aspects of the health care- which has been rarely studied in the health care research, and thus, is not well understood conceptually or empirically, yet it has to be dealt with by academicians, hospital administrators, and public policy makers due to its growing importance in health care services. The study aims to achieve a better understanding of firm- and macro-level implications of a market orientation in the health care environment. Second, this research study explores the importance of having a formal marketing department to develop a market-oriented hospital and improve the hospital's performance. The marketing department serves as an informational link between the hospital and the society. To researchers' best knowledge, the studies that have explored the role of the marketing function within the context of the market orientation in a health care setting are nonexistent. Third, the number of studies that have explored effects of market orientation on hospital performance at the global level has been limited. Another unique aspect of the study in relation to hospital performance is the investigation of the effect of market orientation on the technical performance of hospitals. Finally, even though the effects of market orientation on hospital performance have been explored by few studies that were carried out in various international settings, particularly in the U.S.A., to researchers' best knowledge, no such studies have been conducted on this topic in the Turkish health care context. Consequently, researchers believe that this research will have significant managerial and policy implications for, respectively, hospital administrators and public policy makers since it explores and addresses the potential connections between the firm-level managerial strategies and macro-level public policy concerns.

\section{Sample Selection}

The study was conducted over 400 private hospitals operating in Turkey that were licensed by the Turkish Ministry of Health. According to 2008 Statistical Year Book of Inpatient Treatment Institutions (The latest year book published by the Turkish Ministry of Health), of these licensed private hospitals, 367 were categorized as private company and personal hospitals, 26 as private association and trust hospitals, 5 as private minority hospitals, and finally, 2 as foreign private hospitals (Table 1 ). The state hospitals were not included in this study since it has been assumed that marketing programs, plans and activities are not sufficiently developed and implemented by such hospitals.

Table 1: Distribution of inpatient treatment institutions in Turkey by ownership

\begin{tabular}{lr}
\hline Type of institution & $\begin{array}{c}\text { Number of } \\
\text { hospitals }\end{array}$ \\
\hline Hospitals of Ministry of Health
\end{tabular}

Source: 2008 Statistical Year Book of Inpatient Treatment Institutions

\section{Data Collection}

This study utilized both primary and secondary data collection methods. Then, the secondary and primary data obtained were analyzed together to test some of the proposed research 
hypotheses. The technical performance data of the private hospitals operating in Turkey was obtained from the 2008 Statistical Year Book of Inpatient Treatment Institutions prepared by the Turkish Ministry of Health. Survey research was conducted as a means of primary data collection in this study. The levels of market orientation and general performance of private hospitals were measured through a survey questionnaire. The target respondents for the survey were hospital managers or administrators. The survey was administered via 'face-to-face interview' and 'electronic mail'. Since the research population was large and geographically dispersed and there were time and financial limitations associated with this research study, it was not feasible to interview all the hospital managers face-to-face. Therefore, event though a face-to-face interview was a preferable method of data collection in this study, the e-mail survey method was alternatively used with some participating hospitals for the purposes of increasing the accessibility and participation.

\section{Data Analysis}

Prior to the assessment of the reliabilities of the constructs, the unidimensionality / multidimensionality of all constructs were analyzed (Gerbing and Anderson 1988). To assess the unidimensionality / multidimensionality of the constructs used, each construct was subjected to a Principle Component Analysis (PCA) to verify a single or multiple factor structure. In the principle component analysis, varimax rotation and an Eigenvalue of 1 were utilized. For each construct or dimension, only a single factor structure was obtained. Table 2 presents the summary results of factor analysis of the scale items.

Table 2: Summary results of principle component analysis of scale ýtems

\begin{tabular}{lccc}
\hline Construct & $\begin{array}{c}\text { Number } \\
\text { of items }\end{array}$ & $\begin{array}{c}\text { Number of } \\
\text { factors } \\
\text { extracted }\end{array}$ & $\begin{array}{c}\% \text { of } \\
\text { variance } \\
\text { extracted }\end{array}$ \\
\hline $\begin{array}{l}\text { Market Orientation } \\
\text { Intelligence }\end{array}$ & 5 & 1 & 38.17 \\
$\begin{array}{l}\text { generation } \\
\begin{array}{l}\text { Intelligence } \\
\text { dissemination }\end{array}\end{array}$ & 5 & 1 & 52.96 \\
$\begin{array}{l}\text { Response design } \\
\text { Response imple- } \\
\text { mentation }\end{array}$ & 3 & 1 & 63.38 \\
$\begin{array}{l}\text { General Performance } \\
\text { fenermal }\end{array}$ & 2 & 1 & 66.19 \\
\hline
\end{tabular}

The survey data obtained was analyzed using descriptive statistical methods, regression, factor, and reliability analyses in the Statistical Package for the Social Sciences (SPSS) program. In order to test the proposed four hypotheses, the availability of the marketing department, market orientation, technical performance indicators, and general performance were examined through detailed compared analyses via crosstabulations. Independent two-sample t-tests and F-test statistics were used to test some of the suggested hypotheses.

\section{Measurement Instruments}

The survey questionnaire consisted of 45 questions. Of these questions, 6 questions probed general information on hospitals; 5 questions sought information on hospital managers answering the questions; 32 questions determined the extent to which the participating hospitals are market-oriented; and the remaining 2 questions were asked to determine the general performance of each participating hospital. The questions seeking general information pertaining to the participating hospitals and the individual information pertaining to the hospital administrators were developed on the basis of expert opinions.

The scale that measured the degree of market orientation for each participating hospital was borrowed from Kohli et al. (1993). The survey participants were asked to indicate their agreement / disagreement with the measurement items on a 5-point Likert scale, where 1 meaning 'strongly disagree' and 5 meaning 'strongly agree'. The performance criteria measuring the general performance of each hospital were borrowed from Kohli et al. (1993). The respondents were asked to evaluate their hospital's general performance in a specific year on a 5-point scale, where 1 means 'poor' and 5 means ‘very good'.

In this study, bed occupation ratio, polyclinic-doctor ratio, inpatient-doctor ratio, operationdoctor ratio, patient-bed ratio and bed transfer intervals were used to measure the technical performance of private hospitals. These ratios are good indicators of how well a developing country's health care system and institutions are operating. The technical performance indicators were calculated using the hospital data obtained from the 2008 Statistical Year Book of Inpatient Treatment Institutions. 


\section{Hypotheses}

Market-oriented organizations continuously gather, monitor, and analyze information about customers, competitors, suppliers, and environmental macro factors (Wood et al. 2000). The gathered marketing information is disseminated across functional units or departments within the organization and interpreted and responded (Kohli et al. 1993). The marketing function has a pivotal role in this process. The marketing function or department connects the organization to its external environment (for example, economic, social, legal, technological, competitive, natural factors) and serves as the information and service link for the entire organization. Therefore, having a formal marketing department is very important for the development of a strong market orientation within the organization. The marketing department contributes to organizational performance directly and also indirectly through positively influencing a market orientation. These crucial links between the presence of a marketing department and market orientation and performance are demonstrated in Figure 1 in the context of macro-level drivers and societal outcomes. The supporting evidence for the hypotheses of the proposed framework is discussed below.

\section{Effect of the Marketing Function on Market Orientation}

The marketing function has an important role to play in a market-oriented organization. Moorman and Rust (1999) constructed a framework that explained the boundaries of the marketing function's responsibilities and how it works in a market-oriented firm environment. They investigated the contribution or value of the marketing function as an organization pursues a process or functional structural approach to the management of marketing activities. The research findings revealed that the marketing function is very important for organizations. Moorman and Rust (1999) believe that "the marketing function can and should coexist with a market orientation and... the effectiveness of a market orientation depends on the presence of strong function that includes marketing". They maintained a view that the marketing function has a significant role in the organization with a strong market orientation.

In a contrary argument, however, Slater and Narver (1994b) contended that the marketing function has a less significant role when an or-

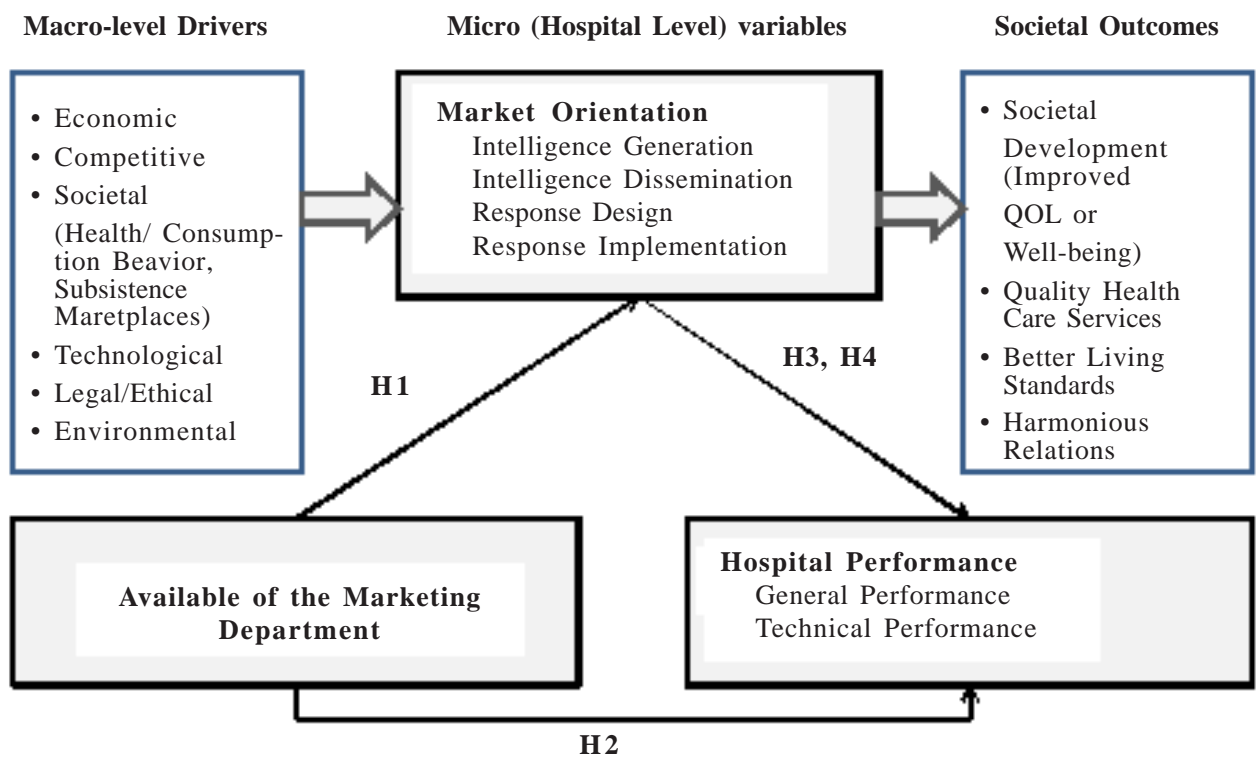

Fig. 1. The framework for the marketing function, market orientation and performance linkages in the health care context of an emerging market 
ganization has a strong market orientation and vice versa. The fact that customer value is created by the contribution of every individual in every functional department of the entire organization implies that developing and maintaining a market orientation in an organization is not a task that is appropriate for only the marketing function. Going further, Slater and Narver (1994b) argued that when a firm develops a strong market orientation throughout the organization, the marketing function is expected to be less important since all other functions are committed to creating and delivering superior customer value. A strong emphasis on cross-functional coordination weakens internal functional boundaries, and eventually, those boundaries lose their meaning (Slater and Narver 1994b; Homburg et al. 2000). Workman et al. (1998) supported this view as well. They proposed that a higher level of market orientation has a "paradoxical effect" on the power of the marketing function within the organization. The higher the number of functional units involving marketing activities, the less the power of the marketing department (Workman et al. 1998). In an organization with a strong market orientation, the marketing function is expected to have less power.

Slater and Narver (1994b) seem to agree with Moorman and Rust (1999) on the significant role of the marketing function in a market-oriented organization only when the organization has a weak market orientation and/or a desire to improve the level of its market orientation. Slater and Narver (1994b) noted that when the organization has a poor market orientation and its internal orientation is based on production or research and development, the marketing function may be required to take an active role in installing market-oriented thinking, and in developing and maintaining a market-oriented culture within the entire organization. They maintained that since its success is dependent on other functional departments for the timely and efficient development, production, and delivery of the product, it would not be surprising for marketing to be the first function that fully appreciates the value of a market orientation. Marketing may demonstrate the advantages of being truly market-oriented to top management and to other functions (Slater and Narver 1994b). As marketing helps the entire organization enhance its market orientation, the role of marketing weak- ens. As a result, marketing's own value and power will suffer.

Overall, based on the preceding discussions, it can be argued that the marketing function is vital to the successful development or enhancement of market orientation in a firm with no or a low level of market orientation (Slater and Narver 1994b). The marketing function provides a rich foundation for market-oriented thinking and behavior to cultivate (Slater and Narver 1994b; Moorman and Rust 1999). The marketing function generates market research data for the organization. This data is used for marketing strategy formulation. Market research data is needed for the development and implementation of a market orientation (Javalgi et al 2006).

The study aims to examine whether the preceding claims made for not-for-profit institutions about the effect of the marketing function on developing a market orientation are also valid in the health care context. Since the market-oriented thinking and practice have only recently developed in the Turkish health care context, it is logical to assume that the current level of market orientation in hospitals would be relatively lower and that market orientation could be considered to be in its infancy stage. So that, in the hospital environment, the marketing function is expected to have a significant effect on all of the four dimensions of market orientation. Thus, whether a formal marketing department or function is available within the hospital's organizational structure will significantly affect the level of market orientation of the hospital. When the formal marketing department or function that effectively carries information from the market to the hospital is available, the hospital is expected to have a higher level of market orientation compared to the hospitals without a marketing department. The marketing department simply connects the society to the hospital. It studies social trends, expectations and values, behaviors and responses of individuals and the larger society and informs the strategic decisions of the hospital.

In relations to the above arguments, researchers hypothese that:

$\boldsymbol{H}_{1}$ : The level of market orientation differs across hospitals depending on the existence or nonexistence of a formal marketing department and it is higher when a formal marketing department is present. 


\section{Effect of the Marketing Function on Hospital Performance}

The question of what role the marketing function should play in a market-oriented organization is a crucial one (Moorman and Rust 1999). Surprisingly, few studies have addressed or investigated the role of the marketing function in a market-oriented organization so far (Workman 1993; Slater and Narver 1994b; Workman et al. 1998; Moorman and Rust 1999). Past researches have discussed the structure/organization of the marketing function (Hise 1965; McNamara 1972; Workman et al. 1998; Moorman and Rust 1999), the role of the marketing function in a marketoriented organization (Slater and Narver 1994b; Workman et al. 1998; Moorman and Rust 1999), and the factors that are likely to affect the power of the marketing function (Workman 1993; Workman et al. 1998).

The marketing department or function is a significant component of an organization. It has an important role "in communicating the needs of the market to all major corporate departments" (McNamara 1972). Moorman and Rust (1999) found that managers from a wide range of businesses and six different functional affiliations viewed marketing as the function which governs various connections between the organization and the customer. The major connections include the customer-product, the customer-service delivery, and the customer-financial accountability connections (Moorman and Rust 1999). Indeed, the product-customer connection is a traditional one. The last two connections have been developed recently as a result of the advancing information technology and the growing service economy (Moorman and Rust 1999). It is assumed that these arguments made for for-profit institutions are also valid for health care institutions and having a formal marketing department at a hospital significantly contributes to the hospital's performance by establishing particularly the patient-service connection. The marketing department brings current intelligence on customers' needs, wants, preferences and behaviors to the hospital. The service/process development activities are performed successfully on the basis of this information. Accordingly, researchers suggested the following hypothesis:

$\boldsymbol{H}_{2}$ : General performance differs across hospitals depending on the existence or nonexistence of a formal marketing department and it is higher when a formal marketing department is present.

\section{Effect of Market Orientation on Hospital Performance}

It has been widely acknowledged that as a company increases its market orientation, its market performance will improve. This view has been shared by both marketing academicians and marketing practitioners for many years (Levitt 1960; Kotler 1984; Webster 1988; Narver and Slater 1990). However, this postulated positive relationship between market orientation and company performance has not been thoroughly investigated until the last two decades. The notion that a market-oriented corporate culture is a key element of a company's superior performance has started to receive a close, intense scholarly attention (Han et al. 1998). Javalgi et al. (2006) suggest that a market orientation leads to better Customer Relationship Marketing (CRM), retention, satisfaction, loyalty, and Lifetime Value (LTV), which in turn, increases company performance. Market-oriented hospitals use market intelligence to understand market problems, threats and opportunities (Loubeau and Jantzen 1998) to face and respond to them.

The prior research on the market orientation and company performance relationship revealed some mixed or inconsistent findings (Diamantopoulos 1993; Hart et al. 1993; Greenley 1995; Han et al. 1998). Some studies found a positive significant relationship between market orientation and business performance (Jaworski and Kohli 1993), while others found a negative significant or no relationship at all between the two constructs (Greenley 1995). Agreeing with the general notion on the relationship between market orientation and organizational performance, researchers postulate the following two hypotheses to be tested in the hospital setting related to the general performance and technical performance of the hospitals:

$\boldsymbol{H}_{3}$ : There is a positive relationship between market orientation and the general performance of the hospital.

$\boldsymbol{H}_{4}$ : The level of market orientation differs across the varying levels of the hospital's technical performance indicators.

\section{RESULTS AND DISCUSSION}

The reliabilities for the market orientation and general performance constructs were calculated using the reliability analysis in the SPSS program (Table 3 ). The coefficient alphas obtained were compared to the cutoff value of 0.70 sug- 
gested by Nunnally (Nunnally 1978). The Cronbach's alpha for the market orientation construct was found to be 0.88 . The component-level reliabilities were calculated as 0.59 for market intelligence generation, 0.78 for market intelligence dissemination, 0.71 for response design, and 0.74 for response implementation. The Cronbach's alpha for the general performance construct was 0.91 . The reliability coefficients for the study constructs, with the exception of that for the market intelligence generation construct, were found to be above the cutoff value of 0.70 . The high reliability coefficients suggest that the study constructs and their measures are reliable and therefore, usable in the context of the private hospitals operating in Turkey.

Table 3: Reliability estimates of model constructs

\begin{tabular}{|c|c|c|}
\hline Construct & $\begin{array}{l}\text { Cronbach } \\
\text { Alpha }\end{array}$ & $\begin{array}{c}\text { Standardized } \\
\text { item Cronbach } \\
\text { Alpha }\end{array}$ \\
\hline Market Orientation & 0.866 & 0.869 \\
\hline Intelligence generation & 0.590 & 0.578 \\
\hline $\begin{array}{l}\text { Intelligence dissemi- } \\
\text { nation }\end{array}$ & 0.775 & 0.777 \\
\hline Response design & 0.708 & 0.708 \\
\hline $\begin{array}{l}\text { Response implemen- } \\
\text { tation }\end{array}$ & 0.740 & 0.743 \\
\hline General Performance & 0.909 & 0.909 \\
\hline
\end{tabular}

\section{Sample Characteristics}

When researchers looked at the distribution of private hospitals within the sample on the basis of the regional location of their operations, researchers saw that, the sample includes a large number of hospitals from the Marmara Region
(44) and the Middle Anatolian Region (27) since these regions have been home to relatively a larger number of private hospitals compared to the other geographical regions in Turkey. These regions are also home to a large number of patients and subsistence marketplaces. While 56 percent of the hospitals that took part in our survey had a formal marketing department that establishes an informational link between the hospital and its marketplaces, partners, communities and the society at large, 44 percent of them did not have a formal marketing department. Marketing activities in these 44 hospitals have been performed by the Department of Public Relations (55 percent, 25 hospitals), General Director (14 percent, 6 hospitals), Purchase Department (9 percent, 4 hospitals), Hospital Manager (7 percent, 3 hospitals), Vice Chief Doctor (2 percent,1 hospital), Patient Relations and Quality Coordination (2 percent,1 hospital), Human Resources (2 percent,1 hospital), Medical Secretary (2 percent, 1 hospital), and Board of Directors ( 2 percent, 1 hospital).

The method of successive waves (Armstrong and Overton 1977) was employed to assess nonresponse bias. In order to test the non-response bias, the late respondents were compared with the early respondents with regard to the selected key variables. The results of the t-tests indicated that there were no statistically significant differences between the early respondents and the late respondents in this study.

To determine whether there is a difference in the levels of market orientation adopted by those private hospitals which have a formal marketing department and those that do not have a formal marketing department, independent two- sample t-tests were conducted. The findings of this analysis were presented in Table 4. According

Table 4: Degree of market orientation by the availability of a formal marketing department

\begin{tabular}{|c|c|c|c|c|c|c|c|c|c|}
\hline \multirow[t]{3}{*}{ Dimensions } & \multicolumn{6}{|c|}{ Availability of marketing department } & \multirow[t]{3}{*}{$t$} & \multirow[t]{3}{*}{$s d$} & \multirow[t]{3}{*}{$p$} \\
\hline & \multicolumn{3}{|c|}{ Yes } & \multicolumn{3}{|c|}{ No } & & & \\
\hline & $n$ & $X$ & S.S. & $n$ & $X$ & S.S. & & & \\
\hline $\begin{array}{l}\text { Market orientation } \\
\text { (Intelligencegeneration) }\end{array}$ & 56 & 3.525 & 0.456 & 44 & 3.266 & 0.506 & 2.686 & 98 & $0.008^{*}$ \\
\hline $\begin{array}{l}\text { Market orientation } \\
\text { (Intelligencedissemination) }\end{array}$ & 56 & 3.304 & 0.390 & 44 & 3.088 & 0.470 & 2.520 & 98 & $0.013^{*}$ \\
\hline $\begin{array}{l}\text { Market orientation } \\
\text { (Response design) }\end{array}$ & 56 & 3.125 & 0.465 & 44 & 2.838 & 0.386 & 3.308 & 98 & $0.001^{*}$ \\
\hline $\begin{array}{l}\text { Market orientation } \\
\text { (Responseimplementation) }\end{array}$ & 56 & 3.434 & 0.474 & 44 & 3.266 & 0.554 & 1.636 & 98 & 0.105 \\
\hline
\end{tabular}


to the table, the mean levels of market intelligence generation ( $3.525 \mathrm{vs.} 3.266$ ), market intelligence dissemination (3.304 vs. 3.088), and market response design (3.215 vs. 2.838) are significantly different across the hospitals depending on the presence of a formal marketing department. However, no difference was found between the mean levels of market response implementation (3.434 vs. 3.266) across those hospitals that have a formal marketing department and those that do not have a formal marketing department. The mean scores of market intelligence generation, market intelligence dissemination, and market response design are significantly higher for the hospitals with a formal marketing department than those hospitals without a formal marketing department. Even, the mean score of market response implementation is also higher for those hospitals that have a formal marketing department even though the difference in the mean scores is not statistically significant. Based on these results, the first hypothesis (H1) of this study that the level of market orientation differs across hospitals depending on the existence or nonexistence of a formal marketing department was accepted.

Further, a one-way variance analysis was conducted to understand whether there are any differences in the mean values of market orientation of private hospitals by the department that executes marketing activities when there is no formal marketing department. According to the results of this analysis, statistically significant differences were found in the mean levels of the market intelligence dissemination ( $\mathrm{p}=0.001$ ) and market response implementation $(\mathrm{p}=0.023)$ components of a market orientation across the five departments which execute various marketing activities in the absence of a formal marketing department. According to Table 5, the mar-

Table 5: Degree of market orientation by department performing marketing activities in the absence of a formal marketing department

\begin{tabular}{|c|c|c|c|c|c|c|}
\hline \multirow[t]{2}{*}{ Dimensions } & \multicolumn{3}{|c|}{ Series statistic } & \multicolumn{2}{|c|}{ Test statistic } & \multirow[b]{2}{*}{$p$} \\
\hline & $n$ & $\bar{X}$ & S.S. & $F$ & $s d_{1}-s d_{2}$ & \\
\hline \multicolumn{7}{|c|}{ Market Orientation (Intelligence Generation) } \\
\hline \multicolumn{7}{|l|}{ Department } \\
\hline Public relations & 24 & 3.425 & 0.487 & 2.378 & $4-37$ & 0.069 \\
\hline General management & 6 & 3.067 & 0.327 & & & \\
\hline Purchasing & 4 & 3.125 & 0.457 & & & \\
\hline Hospital manager & 3 & 3.367 & 0.737 & & & \\
\hline Other & 5 & 2.760 & 0.416 & & & \\
\hline \multicolumn{7}{|c|}{ Market Orientation (Intelligence Dissemination) } \\
\hline \multicolumn{7}{|l|}{ Department } \\
\hline Public relations & 24 & 3.344 & 0.439 & 5.695 & $4-37$ & $0.001^{*}$ \\
\hline General management & 6 & 2.708 & 0.303 & & & \\
\hline Purchasing & 4 & 3.291 & 0.359 & & & \\
\hline Hospital manager & 3 & 2.625 & 0.331 & & & \\
\hline Other & 5 & 2.675 & 0.301 & & & \\
\hline \multicolumn{7}{|c|}{ Market Orientation (Response Design) } \\
\hline \multicolumn{7}{|l|}{ Department } \\
\hline Public relations & 24 & 2.975 & 0.375 & 0.699 & $4-37$ & 0.598 \\
\hline General management & 6 & 2.881 & 0.498 & & & \\
\hline Purchasing & 4 & 2.729 & 0.274 & & & \\
\hline Hospital manager & 3 & 2.667 & 0.577 & & & \\
\hline Other & 5 & 2.600 & 0.370 & & & \\
\hline \multicolumn{7}{|c|}{ Market Orientation (Response Implementation) } \\
\hline \multicolumn{7}{|l|}{ Department } \\
\hline Public relations & 24 & 3.483 & 0.477 & 3.211 & $4-37$ & $0.023^{*}$ \\
\hline General management & 6 & 2.905 & 0.281 & & & \\
\hline Purchasing & 4 & 3.129 & 0.202 & & & \\
\hline Hospital manager & 3 & 2.667 & 0.951 & & & \\
\hline Other & 5 & 3.105 & 0.642 & & & \\
\hline
\end{tabular}

${ }^{*} \mathrm{p}<0.05$ 
ket intelligence dissemination activities (3.344) and market response implementation activities (3.483) are realized at higher rates in hospitals where marketing activities are executed by the department of public relations. This finding indicates that the department of public relations is well-positioned to understand and respond to needs, wants, preferences and behaviors of customers, partners, communities, and subsistence marketplaces in the social milieu of the hospital when there is no formal marketing department. On the contrary, and not surprisingly, marketing activities that are executed under the direct supervision of a hospital manager are realized at the lower levels of a market orientation.

It was determined that there is a statistically significant difference between general performances of hospitals where marketing activities are executed by a formal marketing department and those of hospitals where marketing activities are executed by departments other than a marketing department (Table 6). According to the results of the analysis, it was concluded that the general performance levels of hospitals with a formal marketing department (4.205) are significantly higher than those of the hospitals without a formal marketing department (3.750). A formal marketing department helps hospitals develop right marketing responses, moves and strategies that are welcome by citizens of the society. Based on this result, the second hypothesis (H2) of this study that general performance differs across hospitals depending on the existence or nonexistence of a formal marketing department was accepted. The marketing department serves as a catalyst in the successful functioning of the market information processing in which market intelligence from customers and a larger society is continuously collected, analyzed and responded by the hospital.

In a subsequent analysis of the data, according to Table 7, the general performances of hospitals differ across the departments that execute marketing functions in the absence of a formal marketing department. It was also determined that the general performance of hospitals where marketing activities are executed by the department of public relations is the highest (4.083). The department of public relations develops a better understanding of the health customer behavior and conveys this understanding to every level of the hospital successfully. This understanding helps the hospital develop better services for patients and better solutions to societal problems and in turn, perform better. Besides, the general performance level of hospitals where marketing activities were executed by a hospital manager is the lowest (2.667).

For the purpose of determining whether there is a relationship between market orientation and

Table 6: General performance of hospitals by the availability of a formal marketing department

\begin{tabular}{|c|c|c|c|c|c|c|c|c|c|}
\hline \multirow[t]{3}{*}{ Dimensions } & \multicolumn{6}{|c|}{ Availability of marketing department } & \multirow[t]{3}{*}{$t$} & \multirow[t]{3}{*}{$s d$} & \multirow[t]{3}{*}{$p$} \\
\hline & \multicolumn{3}{|c|}{ Yes } & \multicolumn{3}{|c|}{ No } & & & \\
\hline & $n$ & $X$ & S.S. & $n$ & $X$ & S.S. & & & \\
\hline General performance & 56 & 4.205 & 0.699 & 44 & 3.750 & 0.789 & 3.055 & 98 & $0.003^{*}$ \\
\hline
\end{tabular}

${ }^{*} \mathrm{p}<0.05$

Table 7: General performance of hospitals by department performing marketing activities in the absence of a formal marketing department

\begin{tabular}{|c|c|c|c|c|c|c|c|}
\hline \multirow[t]{2}{*}{ Dimensions } & \multicolumn{3}{|c|}{ Series statistic } & \multicolumn{3}{|c|}{ Test statistic } & \multirow[b]{2}{*}{$p$} \\
\hline & $n$ & $X$ & S.S. & $F$ & $s d_{1}-s d_{2}$ & & \\
\hline \multicolumn{8}{|c|}{ General performance } \\
\hline \multicolumn{8}{|l|}{ Department } \\
\hline Public relations & 24 & 4.083 & 0.408 & 6.477 & $4-37$ & $0.000^{*}$ & \\
\hline General management & 6 & 3.750 & 0.880 & & & & \\
\hline Purchasing & 4 & 3.875 & 0.250 & & & & \\
\hline Hospital manager & 3 & 2.667 & 0.577 & & & & \\
\hline Other & 5 & 2.800 & 1.304 & & & & \\
\hline
\end{tabular}

* $\mathrm{p}<0.05$ 
general performance of hospitals, a regression analysis was carried out. According to the regression results (Table 8), market orientation positively influences general performance of private hospitals $(\mathrm{p}<0.05)$. This is a clear indication of the fact that when hospitals effectively interact with their patients and a larger society and have shown some sensitivity towards their needs and demands, the society responds back in a positive way that helps hospitals improve their performance. At the component-level, the three components of market orientation have statistically significant positive effects on general performance of the private hospitals. As it can be seen from Table 8, general performance is affected by market intelligence generation, market information dissemination, and market response implementation at the 0.05 significance level. As a result, it is safe to conclude that as hospitals get more market-oriented, their general performance level increases. Thus, the third hypothesis (H3) of this study that there is a positive relationship between market orientation and general performance of the hospital was accepted.

In the present study, bed occupation ratio, polyclinic-doctor ratio, inpatient-doctor ratio, operation-doctor ratio, patient-bed ratio and bed transfer intervals were used to measure technical performance of the private hospitals. These ratios are expected to better represent the outcomes of being market-oriented since these measures are directly related to the quality expectations of the society about health care services provided by hospitals. The different levels of each technical performance ratio were compared with each other in terms of the level of market orientation each level is associated with. According to the results of the one-way variance analyses conducted, no statistically significant differences were found between the mean values of the four dimensions of market orientation across the different levels of each technical performance ratio or indicator ( $>>0.05)$. Based on the results of the statistical analyses, the fourth hypothesis (H4) of this study that the level of market orientation differs across the varying levels of the hospital's technical performance indicators was rejected. The six tables containing the results of these analyses were not included in this manuscript due to their large size, however, they will be made available upon request.

\section{CONCLUSION}

The purposes of the study were to determine the effects of market orientation on performance of the private hospitals in Turkey and explore the role of the formal marketing department in the development of a market orientation. This study also investigated which department or person took over the responsibilities of the marketing function when there is no formal marketing department.

The current study investigated the relationship between market orientation and performance at the component level in the private hospital setting of the Turkish health care market. This study also explored the role of a formal marketing department in the development of a market orientation in private hospitals. These empirical links were explored in the light of macro-level drivers and societal outcomes of a market orientation in the health care sector. Based on the results of this study, it is suggested that hospitals should focus on adopting and developing market orientation at a large scale for the purposes of increasing hospital performance and

Table 8: Effect of market orientation on general performance

\begin{tabular}{|c|c|c|c|c|c|c|}
\hline \multirow[t]{2}{*}{$\begin{array}{l}\text { Model: } \\
\text { General }\end{array}$} & \multirow[t]{2}{*}{ Performance } & \multicolumn{2}{|c|}{$\begin{array}{c}\text { Unstandardized } \\
\text { coefficients }\end{array}$} & \multirow{2}{*}{$\begin{array}{c}\begin{array}{c}\text { Standardized } \\
\text { coefficients }\end{array} \\
\text { Beta }\end{array}$} & \multirow[t]{2}{*}{$t$} & \multirow[t]{2}{*}{$P$} \\
\hline & & $B$ & Std. error & & & \\
\hline \multirow[t]{3}{*}{1} & (Constant) & 1.723 & .761 & & 2.264 & $.026^{*}$ \\
\hline & Market orientation & .097 & .012 & .645 & 8.363 & $.000^{*}$ \\
\hline & (Constant) & 1.886 & .832 & & 2.266 & $.026^{*}$ \\
\hline \multirow[t]{4}{*}{2} & Intelligence generation & .113 & .041 & .268 & 2.773 & $.007^{*}$ \\
\hline & Intelligence dissemination & .124 & .053 & .315 & 2.317 & $.023^{*}$ \\
\hline & Response design & -.062 & .089 & -.086 & -.701 & .485 \\
\hline & Response implementation & .167 & .065 & .279 & 2.567 & $.012^{*}$ \\
\hline
\end{tabular}

${ }^{*} \mathrm{p}<0.05$ 
achieving positive societal outcomes. In doing so, hospitals should not underestimate the vital role a formal marketing department which serves as the information link between the hospital and the society plays in the development of marketoriented hospital strategies and operations.

\section{RECOMMENDATIONS}

The results of this study have several important practical implications for hospitals. First, the research results suggest that it is very critical for hospitals to have a formal marketing department. The results indicated that only 56 percent of the private hospitals that participated in the survey had a formal marketing department and marketing-related activities were mainly executed by the department of public relations in the 44 hospitals that had no marketing department. This finding is very alarming since, according to our analyses, the availability or unavailability of a formal marketing department has an important effect on the level of market orientation of the hospital. When a formal marketing department is available, the hospital tends to exhibit a higher level of market orientation and, at the component level, this translates into higher levels of market intelligence generation, market intelligence dissemination, and market response design and overall effective interactions with customers and the society at large. This finding suggests that a hospital that strives to develop a strong market orientation needs to establish a well-functioning marketing department as the first step. When the functions of a marketing department are assigned to another department or a single person in the absence of a formal marketing department, according to the study results, the levels of market intelligence dissemination and market response implementation significantly differ across the departments that perform marketing tasks and activities for the hospital (that is, public relations, general management, purchasing, hospital manager, and other).

Besides, the study results indicated that the hospitals that have a formal marketing department outperform the hospitals that do not have a formal marketing department. This is a particularly significant finding that highlights the powerful effect a marketing department has on the general performance of the hospital. In a further analysis on this issue, it was determined that, the general performance of hospitals differs across the departments that perform marketing activities in the absence of a formal marketing department. According to this, the general performance of hospitals in which marketing activities are executed by the department of public relations is higher.

It was found out that there is a significant positive relationship between market orientation and general performance $(p<0.05)$. At the component level, market intelligence generation, market intelligence dissemination and market response implementation have positive impacts on the general performance of the hospital. In addition, it can be safely concluded that as hospitals become more market-oriented and more responsive to needs of health care customers, and their general performance levels increase.

When considering that market orientation significantly increases performance of a hospital, it is clearly understood that each hospital is obliged to create a formal marketing department which will be responsible for performing the hospital's very essential marketing activities. Managers need to strive to adopt and develop a market orientation in their organizations. Developing market-oriented hospital operations and services is a challenging task. It requires a top-tobottom organizational change. The commitment and leadership of the top management are very critical for the success of this development effort. Providing all of the hospital employees necessary training and education on market orientation and putting aside resources for this purpose are important tasks for hospitals that may lead to considerable success.

No difference between each of the four dimensions of the market orientation construct and each of the technical performance indicators used was determined. Consequently, it was concluded that market orientation does not influence any technical performance indicators of a hospital. This result is not surprising given that most of the technical performance indicators used in this study require long-term investments in additional health care facilities, bed capacity, polyclinic and inpatient services, health workforce, and so on. These investments have the highest potential to contribute to the well-being of the society, yet they are costly and take a long time. Market orientation is likely to encourage hospitals to make these types of investments in the longrun. Even though the level of market orientation 
is high in some hospitals in our sample, the real effects of market orientation on technical performance indicators and consequently on the society's well-being may not be seen until some years later due to the long-term nature of market orientation and technical performance measures.

Hospitals function in a complex social milieu. They are responsible for providing quality health services for the well-being of the communities they serve. Health is an important component of the QOL. Hospitals can affect the societal development of a county through the services they provide by enhancing the QOL of the society. Due to their apparent powerful role in the well-being or QOL of the society, how hospitals operate and how well they perform have to be great concerns to public policy makers in every society. Even though operations, policies and marketing strategies of hospitals seem to be micro-level issues and concerns, they have macro-level ramifications for the whole society. Hence, how effectively micro-level functions and processes at hospitals are being managed should be a public concern.

What kind of policies and programs can be initiated by public policy makers to support market-oriented hospitals in their endeavors to impact the societal development by improving the QOL or well-being of the society is a critical macromarketing question that should be answered. First, data collection by hospitals can be made easier. Administrators at hospitals need primary and/or secondary data to make decisions on strategic marketing matters. Providing a convenient access to critical medical data sources on patients across all health care institutions in a country could be a good starting point. Sharing of medical records across hospitals for research and development purposes could make a significant difference in service development by hospitals. Further, accessing to the medical research results of educational and scientific institutions can be made convenient and cost-free for health care professionals and institutions. Data storing (databases and warehouses), retrieving and analysis (data mining) and data sharing among organizations are well-advanced in developed nations, but this is not so much so in developing nations like Turkey. Sometimes, in developing nations, it makes sense for the government to intervene and organize and coordinate data collection (on scientific research, medical records, consumer behavior, demographics, economic trends, etc.) centrally and to provide vital data to hospitals for free. Second, hospitals or hospital systems should have in-house marketing research departments or house marketing research specialists in their marketing departments. Primary data collection should be performed professionally since this is where the hospital interacts with its current and potential customers and the society at large. The hospital's interactions with human subjects and the overall society in the market research settings should clearly be regulated by the government. Third, recognizing and awarding market-oriented health care institutions that make patient satisfaction a priority and contribute substantially to the well-being of the society. These are small steps that could be taken by public policy makers toward working with hospitals to strengthen the QOL for all members of the society.

\section{FUTURE SCOPE OF THE STUDY}

It is strongly suggested that future research investigates the proposed links in the present research framework using a multiple-informant approach. This will reduce measurement error in research. Possible lagged effects of market orientation on technical performance indicators should be examined in longitudinal studies since technical performance indicators of hospitals are directly associated with the capacity and quality of hospital services that affect the QOL of the society. Additionally, future research should explore thoroughly the extent of the marketing function's role in creating a market-oriented hospital and try to develop theories on this important topic. How a strong marketing department in hospitals can contribute to the well-being of the society and the institution is an important research question that should explored by future studies.

\section{LIMITATIONS}

While managers from the hospitals that are located in Ankara and Istanbul were interviewed face-to-face, an electronic survey was used for those hospitals in other provinces in Turkey. For this, an online copy of the questionnaire was created using an online survey design program. The web link to the survey was generated and sent to all of the private hospitals in Turkey together with 3 waves of reminding notes or emails. Thanks to this mixed method of data collection, 108 questionnaires out of 400 question- 
naires that had been sent were returned, 8 questionnaires were excluded from the final sample because of the missing data and the remaining 100 questionnaires were deemed usable and included in the analyses.

\section{REFERENCES}

Armstrong JS, Overton TS 1977. Estimating non-response bias in mail surveys. Journal of Marketing Research, 14(3): 396-402.

Arnold DR, Capella LM, Sumrall DA 1987. Organization culture and the marketing concept: Diagnostic keys for hospitals. Journal of Health Care Marketing, 7(1): 18-28.

Berkowitz EN 2010. Essentials of Health Care Marketing. $3^{\text {rd }}$ Edition. Sudbury, MA: Jones and Bartlett Learning.

Chance Z, Deshpande R 2009. Putting patients first: Social marketing strategies for treating HIV in developing nations. Journal of Macromarketing, 29(3): 220-232.

Day GS 1994. The capabilities of market-driven organizations. Journal of Marketing, 58(4): 37-52.

Deshpande R, Farley JU, Webster FE Jr 1993. Corporate culture, customer orientation, and innovativeness in Japanese firms: A quadrad analysis. Journal of Marketing, 57(1): 23-27.

Dominique C, Chebat JC 2013. Health marketing: Toward an ýntegrative perspective. Journal of Business Research, 66: 123-126.

Gerbing D, Anderson J 1988. An updated paradigm for scale development incorporating unidimensionality and its assessment. Journal of Marketing Research, 25(5): 186-192.

Greenley GE 1995. Market orientation and company performance: Empirical evidence from UK companies. British Journal of Management, 6(1): 1-13.

Han JK, Kim N, Srivastava RK 1998. Market orientation and organizational performance: Is innovation a missing link? Journal of Marketing, 62(4): 30-45.

Harris GE 2007. Sidney levy: Challenging the philosophical assumptions of marketing. Journal of Macromarketing, 27(1): 7-14.

Hart S, Diamantopoulos A 1993. Linking market orientation and company performance: Preliminary work on Kohli and Jaworski's Framework. Journal of Strategic Marketing, 1(2): 93-122.

Hise RT 1965. Have manufacturing firms adopted the marketing concept? Journal of Marketing, 29(3): 9-12.

Homburg C, Workman JP Jr, Jensen O 2000. Fundamental changes in marketing organization: The movement toward a customer-focused organizational structure. Journal of the Academy of Marketing Science, 28(4): 459-478.

Hurley RF, Tomas G, Hult M 1998. Innovation, market orientation, and organizational learning: An ýntegration and empirical examination. Journal of Marketing, 62(3): 42-54.

Javalgi RG, Martin CL, Young RB 2006. Marketing research, market orientation and customer relationship management: A framework and implications for service providers. Journal of Services Marketing, 20(1): 12-23.

Jaworski BJ, Kohli AK 1993. Market orientation: Antecedents and consequences. Journal of Marketing, 57(3): 53-70.

Jaworski BJ, Kohli AK 1996. Market orientation: Review, refinement, and roadmap. Journal of Focused Management, 1(2): 119-135.

Keller PA, Lehmann DR, Milligan KJ 2009. Effectiveness of corporate well-being programs: A meta-analysis. Journal of Macromarketing, 29(3): 279-302.

Kilbourne WE 2008. How macro should macromarketing be? Journal of Macromarketing, 28 (2): 189191.

Kohli KA, Jaworski BJ 1990. Market orientation: The construct, research propositions and managerial implications. Journal of Marketing, 54(2): 1-18.

Kohli KA, Jaworski BJ, Kumar A 1993. Markor: A measure of market orientation. Journal of Marketing Research, 30(4): 467-477.

Kumar K, Subramanian R, Yauger C 1998. Examining the market orientation-performance relationship: A context-specific study. Journal of Management, 24(2): 201-233.

Kumar K, Subramanian R 2000. Navigate the external environment through a market orientation. SAM Advanced Management Journal, 65(1): 16-22.

Kotler Philip 1982. Marketing For Non-profit Organizations. New Jersey: Prentice-Hall.

Levitt T 1960. Marketing myopia. Harvard Business Review, 38(4): 45-56.

Loubeau PR, Jantzen R 1998. Marketing research activities in hospitals. Marketing Health Services, 18(1): 12-17.

McNamara CP 1972. The present status of the marketing concept. Journal of Marketing, 36(1): 5057.

Mitchell RW, Wooliscroft B, Higham J 2010. Sustainable market orientation: A new approach to managing marketing strategy. Journal of Macromarketing, 30(2): 160-170.

Moorman C, Rust RT 1999. The role of marketing. Journal of Marketing, 63(4): 180-197.

Naidu GM, Narayana CL 1991. How marketing oriented are hospitals in a declining market? Journal of Health Care Marketing, 11(1): 23-30.

Narver JC, Slater SF 1990. The effect of a market orientation on business profitability. Journal of Marketing, 54(4): 20-34.

Nunnally JC 1978. Psychometric Theory. New York: McGraw Hill.

Pelham A, Wilson DT 1995. Does Market Orientation Matter for Small Firms? Working Paper No. 95102:1-35. Cambridge, MA: Marketing Science Institute.

Peterson M 2006. Identifying quality-of-life priorities for societal development: Using citizens. Journal of Macromarketing, 26(1): 45-58.

Rahtz, DR, Szykman LR 2008. Can health care organizations better contribute to quality of life by focusing on preventive health knowledge? Journal of Macromarketing, 28(2): 122-129.

Raju PS, Lonial SC, Gupta YP 1995. Market orientation and performance in the hospital industry. Journal of Health Care Marketing, 15(4): 34-41. 
Raju PS, Lonial SC, Gupta YP, Ziegler C 2000. The relationship between market orientation and performance in the hospital industry: A structural equations modeling approach. Health Care Management Science, 3(3): 237-247.

Samli AC 2010. The medical services paradox in the U.S. market system: The desperate need for improvement. Journal of Macromarketing, 30(4): 398-401.

Shankar V, Carpenter GS 2012. Handbook of Marketing Strategy. Massachusetts: Edward Elgar Publishing.

Slater SF, Narver JC 1994a. Does competitive environment moderate the market orientation-performance relationship? Journal of Marketing, 58(1): 46-55.

Slater, SF, Narver JC 1994b. Market orientation, customer value, and superior performance. Business Horizons, 37(2): 22-28.

The University of Illinois at Urbana-Champaign 2014. Subsistence Marketplaces Initiative. From <http:// business.illinois.edu> (Retrieved on 5 May 2014).

Varey RJ 2013. Marketing in the flourishing society megatrend. Journal of Macromarketing, 33(4): 354368.
Viswanathan M, Seth A, Gau R, Chaturvedi A 2009. Ingraining product-relevant social good into business processes in subsistence marketplaces: The sustainable market orientation. Journal of Macromarketing, 29(4): 406-425.

Webster FE Jr 1988. The rediscovery of the marketing concept. Business Horizons, 31(3): 29-39.

Wood RV, Bhuian S, Kiecker P 2000. Market orientation and organizational performance in not-for-profit hospitals. Journal of Business Research, 48(3): 213-226.

Workman JP Jr, 1993. Marketing's limited role in new product development in one computer systems firm. Journal of Marketing Research, 30(11): 405-421.

Workman JP Jr, Homburg C, Gruner K 1998. Marketing organization: An integrative framework of dimensions and determinants. Journal of Marketing, 62(3): 21-41.

Wrenn B 2002. Contribution to hospital performance: Market orientation vs. marketing effort and lack of competition. Journal of Hospital Marketing and Public Relations, 14(1): 3-13. 